\title{
Benefits of Breast Milk for Health Care: Analysis from the Islamic Perspective
}

\author{
Normadiah Daud $^{1^{*}}$, Hamizah Ismail ${ }^{2}$, Siti Roshaidai Mohd Ariffin ${ }^{3}$, \\ Rahimah Embong ${ }^{1}$, Nadhirah Nordin ${ }^{1}$, Ado Abdu Bichi ${ }^{4}$ \\ ${ }^{1}$ Faculty of Islamic Contemporary Studies, Universiti Sultan Zainal Abidin, Malaysia, ${ }^{2}$ Kulliyyah of Medicine, \\ ${ }^{3}$ Kulliyyah of Nursing, International Islamic University Malaysia, ${ }^{4}$ Faculty of Education, \\ Yusuf Maitama Sule University, Kano Nigeria
}

\begin{abstract}
Breastfeeding truly gives an enormous effect towards the health of a mother and child. Breast milk contains nutrients which are highly beneficial for an infant's health and growth. Among other benefits for a baby is it helps to develop the baby's intelligence, it is very clean and it can save a baby from various diseases. There are lots of explanations in Islam with regards to the important position of breast milk in the life of a child however; there is lack of empirical evidences pointing out the importance of breastfeeding for health care from the Islamic perspective. In view of these the present paper aimed at studying the importance of breastfeeding for both child and mother according to the perspectives of Islam. This research is based on literature review method. Data was collected through documents analysis which consists of turath (traditional) and modern books as well as articles related to breastfeeding. The review revealed the importance of breast milk for a baby's health; apparently the opinions of scientists are in parallel with the opinions of fuqaha. In fact, fuqaha from Shafi'i and Hambali sects obliged the feeding of al laba' which is colostrum to newborn babies. Conclusively, Muslims are made by the Islamic injunctions to believe that breast milk is just an effort to prevent a child and a mother from being inflicted with any diseases. This paper provides an important highlight that the breastfeeding is not only significance according to science but also because it fulfils the syarak requirements.
\end{abstract}

Keywords: Breast milk, Health Care, Islamic Perspective.

\section{Introduction}

Breast milk is the best food for babies especially right after birth until about 6 months old. It contains all the nutrients in the right amount. Breast milk also contains colostrum which helps to fight infections from numerous diseases such as diarrhea, cold and pneumonia. Furthermore, it acts as the first immunization for newborn babies ${ }^{1}$. The benefits of breastfeeding are also in parallel with Allah's commandment in surah al-Baqarah verse 233 which advocates mothers to breastfeed their children up until the age of two. In fact

\section{Corresponding Author** Normadiah Daud}

Associate Professor, Faculty of Islamic Contemporary Studies, Universiti Sultan Zainal Abidin, Malaysia e-mail: normadiah@unisza.edu.my there are numerous hadiths and opinions of fuqaha (experts in Islamic jurisprudence) and sahabiyat (female companions of Prophet SAW) that, discussed the benefits of breast milk.

Therefore the objective of this research is to study the importance of breast milk from the science perspective while at the same time, analyzing it based on the Islamic perspective. Previous researches especially turath books focused primarily on the significance of breastfeeding based on the Islamic perspectives only. For example, literatures produced by ${ }^{2,3,4}$ and many others. They only discussed the concept and advantages of breastfeeding from the Islamic perspectives while breastfeeding from the aspect of science was not clearly mentioned.

In Malaysia there are numerous literatures with regards to breastfeeding. Examples include ${ }^{5,6,7,8,9}$ and others. These literatures present the benefits of breast milk from the aspect of science, and they advocate 
breastfeeding. Analysis based on the Islamic perspectives on the science aspects was not carried out. Therefore, the authors saw a loophole in the previous researches hence this paper will discuss both aspects; the benefits of breast milk based on science and the analysis based on the Islamic perspectives.

Benefits of Breast Milk for Health Care: Some of the benefits of breast milk for babies is it can enhance baby's brain, it is guaranteed clean, it can save lives and avoid obesity problems among babies and many others. Breastfeeding is indeed closely related to children's mental health. A group of researchers from Adelaide's Flinders Medical Center, USA conducted an intelligence test on 32 babies. From that test they found that babies who were breastfed were $40 \%$ smarter that babies who drink formula milk. This research proves that DHA (kind of fat acid contained in breast milk that increases baby's mental development) is really beneficial for baby's brain development ${ }^{10}$

Scientific studies also show that brain ability for babies who are given breast milk is better than other babies. A study showed that breast milk given to babies during the first 6 months is highly beneficial for babies' intelligence, and babies who were breastfed for less than 8 weeks obtain fewer benefits for their IQ developments ${ }^{11}$. Therefore, babies who are given breast milk obtain the best nutrition for their brain and nerve developments ${ }^{12}$.

Other than that, breast milk can save babies lives. This is owing to the fact that most diseases can be avoided with breastfeeding. Breast milk is clean and bacteria-free. Besides, it contains anti-infection agent that can fight numerous infectious diseases. One of the agents is the live white blood cells (leucocytes) that kill bacteria. Meanwhile, antibodies (immunoglobulins) can fight against the infection of regular diseases until the baby is capable of forming his or her own antibodies. This is due to an agent called bifudus factor that helps some special bacteria called Lactobasillus bifidus to breed and fight against bacteria that causes diarrhea. Other than diarrhea, breast milk has successfully fought against normal infections such as eczema, asthma and constipation. Babies who were given breast milk also rarely have ear or respiratory problems as compared to babies who were given formula milk. The nutrients in breast milk may also prevent babies from getting allergies. A research done in Finland showed that breastfeeding protects babies from any allergies from small to adulthood ${ }^{13}$.

In Mexico, 118 underweight babies were given breast milk or formula milk. This experiment showed that babies who were given formula milk were 13 times more prone to have bowel inflammation such as necrotizing enterocolitis and five times more prone to urinary tract diseases. In addition, they are also nine times more exposed to diarrhea ${ }^{14}$. Besides controlling diseases, breastfeeding may reduce the risk for a baby to be severely obese at a young age ${ }^{15}$. There are many researches that showed babies who consume formula milk early after birth are more prone to be obese ${ }^{16}$.

Benefits of Breast Milk from the Islamic Perspectives: The science world knows that the biggest secret contained in breast milk which makes it so beneficial is the existence of colostrum which forms antibody that preserve baby's health. This view has actually being dominated by early Islamic scholars. For example, in the Shafi' $i$ sect it is stated that a mother is obligated to feed her child with al laba' or colostrum which is the first milk that comes out after the delivery. This is because a baby normally cannot live without consuming that first milk ${ }^{17}$. Similarly, the opinions in Hanbali sect ${ }^{18}$ also obliged the feeding of al laba or colostrum for newborn babies because it is extremely important for the babies' lives and usually a baby cannot live without $i^{17}$. This matter is befitting to qawa'id fiqhiyyah: Harm is eliminated ${ }^{19}$.

The verity on scientific research which stated breast milk is an agent or catalyst for babies' intelligence has long been proven in Islamic history ${ }^{20}$. One wellknown event in the Islamic history is the story of breastfeeding story of Imam al-Haramayn ${ }^{21}$. When he (Imam al-Haramayn) was little he was nursed by a stranger because his mother was sick. His father, upon knowing this, straightaway forced the milk out from al-Haramayn's stomach. Imam al-Haramayn was only allowed to drink milk from his mother who was a pious and obedient servant to Allah SWT. As a result, Imam al-Haramayn grew up to become a faithful servant of Allah who was brilliant in Islamic knowledge. Imam alHaramayn would mention this story many times to his audience whenever his speech was interrupted. He said:

This is the leftovers of the milk (from a stranger): From what has been uttered by Imam al-Haramayn, it was clear that he acknowledged that all privileges given by Allah SWT to him was the effect of proper breastfeeding from his mother ${ }^{21}$. As a lesson, if a mother 
has no milk then she must find breast milk from another woman with virtuous character and manners. They are not encouraged to straight away resolve to formula milk when obstacles arise to breastfeed because there is no other food better than breast milk.

${ }^{22}$ a Muslim breastfeeding expert from America had written in her article titled The Importance of Breastfeeding to the Muslim Child that breastfeeding will produce babies with higher IQ and more stable emotion. This finding is supported by a child specialist in Turkey in his article Breast-feeding in Islam. His 10 years research in child study had proven that breast milk nutrients can increase a baby's IQ. According to him, breast milk contains a very high taurine. Taurine is one of the amino acid which is extremely crucial for brain development. This fact is more interesting to be studied because taurine content in human's milk is 30 to 40 times higher than cow's milk ${ }^{23}$.

Mothers should always increase Qur'an recitations and other ibadah when breastfeeding. This will help the child to absorb all virtues done by the mother during the nursing period. If a mother is incapable of breastfeeding, then she must give the child to a pious, noble and smart woman as a wet nurse. She should never give her child to be breastfed by someone with unknown lineage or religion. It is afraid that the feeding may distort brain development and manners of the baby. This statement is enforced by a mursal hadith:

\section{From Ziyad al-Sahmi he said: Rasulullah SAW forbids} from asking dumb women to breastfeed children.

(Sunan Kubra, The Book of Marriage, Al-murdi' alHamqa' chapter, Hadith no: 4172)

Verily all diseases and disasters come from Allah SWT to test humans' faith and to cleanse their sins. Nevertheless, as a servant of Allah SWT with a sound mind, one must make an effort to avoid diseases and find a cure when he falls sick from any diseases. One of the treatments recommended in Islam is by performing injunctions in the Quran and hadith nabawiyyah. One of the methods advocated in Islam to avoid diseases is through the habit of eating for babies - through breastfeeding until the age of two. This ruling is stated in Surah al-Baqarah verse 233. According to Mohamad 'Abduh, breastfeeding affect all aspects including in terms of diseases prevention ${ }^{24}$.

Several studies carried out by researchers that recognized the effectiveness of breastfeeding as a family planning method. Nevertheless, breastfeeding is just an effort by human, if Allah wills it, pregnancy will still occur. This is befitting to His commandment in surah Yasin:

\section{Verily when He intends a thing His command is "Be" and it is. (Yasin: 82)}

Al-Qurtubi suggested, when Allah SWT wills for something to happen, it happens without the need for any help or without any difficulties. Similarly, Allah SWT in His commandment stated that:

We did not idly create the heavens and the earth and all that lies between them. (Al-Dukhan: 38)

Al-Zuhayli in Tafseer al-Munir, translated this verse as everything the Allah created has its own wisdom and purpose. There is not a creation by Allah which is useless. What is more important is a decree or creation serves as an evidence of Allah SWT's mightiness and oneness ${ }^{25}$.

Therefore one of the creation and instruction of Allah SWT is the instruction to breastfeed. Among the biggest wisdom is it contributes to the mother's health. However, when mothers avoided breastfeeding their children, numerous harms will inflict on mothers themselves. Numerous diseases due to failure in breastfeeding may inflict upon the mothers whereas Islam forbids its people from getting involved in things that may inflict harm upon themselves. Islam truly forbids such act as stated in fiqh method previously.

Breast milk is the best food; it is clean, halal, nutritious and costless. Nevertheless, those are not the only things desired by breastfeeding mothers. What is more important is breastfeeding is an instruction by Allah SWT which is clearly written in the Qur'an. Therefore, surely mothers who breastfeed their children are not only providing the best food the children but also getting multiple rewards from Allah SWT.

\section{Conclusion}

From the above discussions, it is prevalent that breastfeeding truly gives a huge impact towards the health of a mother and child. Breast milk contains nutrients which are highly beneficial for an infant's health and growth. Among other benefits for a baby is it helps to develop the baby's intelligence, it is very clean and it can save a baby from various diseases such as diarrhea, allergies, otitis media, obesity and others. 
Concurrently, Islam advocates breastfeeding because not only it gives an added advantage towards the children and the mothers' physical health as studied by scientists; it also contributes to children's mental health characters.

Looking at the aspect of the importance of breast milk for a baby's health, apparently the opinions of scientists are in parallel with the opinions of fuqaha. In fact, fuqaha from Shafi'i and Hambali sects obliged the feeding of al laba' which is colostrum to newborn babies. This is owing to the importance of colostrum for a baby's growth and development. This superiority has been greatly emphasized by scientists today that most hospitals even ban the use of milk bottles and formula milk early after birth. Conclusively, as Muslims, we must believe that breast milk is just an effort to prevent a child and a mother from being inflicted with any diseases. This is because breast milk is an Allah's creation which is amazing and perfect.

Acknowledgement: We express our deepest gratitude to Faculty of Islamic Contemporary Studies, Universiti Sultan Zainal Abidin as well as Kulliyyah of Medicine and Kulliyyah of Nursing, International Islamic University Malaysia.

\section{Conflict of Interest: Nil}

Funding: Faculty of Islamic Contemporary Studies and Center for Research Excellence \& Incubation Management (CREIM), Universiti Sultan Zainal Abidin Universiti Sultan Zainal Abidin under University Grant (/ UNISZA/FKI/2018/01).

Ethical Clearance: Obtained through Research Committee

\section{References}

1. Syeikh A. Breastfeeding Aspects of Nutrition, Development and Baby Health. Kuala Lumpur: Language and Library Council. 1996.

2. Ibn Rushd Abu al-Walid Muḥammad bin Aḥmad, Bidayat al-Mujtahid wa Nihayat al - Muqtașid, Dar al Fikr, Beirut. t.th., Vol. 2,

3. Al-Bahuti MI. Kashshaf al-Qina' 'an Matn alIqna', Dar 'Alam al-Kutub, Saudi Arabia. 2003.

4. Rita RO. Hebatnya Susu Ibu, Karangkraf Book Group, Kuala Lumpur, 2012.

5. Ghazali S. Menyusukan B. Overcoming mental and social barriers. Utusan Publications \& Distributors Sdn. Bhd, Kuala Lumpur; 1998.
6. Abdul-Kader H. Child Care Guidelines for Child Health, Utusan Publication \& Distributors Sdn. Bhd, Kuala Lumpur; 1986.

7. Abdul-Hamid A. Baka dan Zuriat. Kuala Lumpur: S. Abdul Majeed Company; 1991.

8. Nor Ashikin M, Sentuhan K, Utusan Publications \& Distributors SDN. BHD, Kuala Lumpur; 2006.

9. Arini. H, Why a Mother Should Have a Baby? Al Risalah Product SDN. BHD, Kuala Lumpur, 2013, pp. 50-54.

10. Lifshitz F. Nutrition for Special Need in Infancy. New York: Marcel Dekker Inc. 1995.

11. Whitmire T. IQ Gain from Breastfeeding. Accessed from http://abcnews.go.com/sections/living/Daily News/breastfeeding; 23 ${ }^{\text {rd }}$ September 2010.

12. Danial ZA. Scientific Qur'an Explores the Qur'an's Excellence From Science Binoculars. Kuala Lumpur: PTS Millenia; 2010.

13. Vennemann MM, Bajanowski T, Brinkmann B, Jorch G, Yücesan K, Sauerland C, Mitchell EA. Does breastfeeding reduce the risk of sudden infant death syndrome?. Pediatrics. 2009 Mar 1; 123(3):e406-10.

14. Anon. $15^{\text {th }}$ October 2010. Breast Milk Helps Reduce Obesity. Accessed from http://news.bbc. co.uk/2/hi/health $/ 3673149$. stm

15. Armstrong J. \& Reilly JJ. Breastfeeding and lowering the risk of childhood obesity. Lancet, 2002, 359: 9322.

16. Li R, Fein SB, Grummer-Strawn LM. Do infants fed from bottles lack self-regulation of milk intake compared with directly breastfed infants? J Am Ac of Pediatrics, 2010 125(6): 1386.

17. Al-Sharbini, Muhammad al-Khațib. Mughni alMuhtaj ila Ma'rifat Ma'ani Alfaẓal-Minhaj, Dar Ihya' al-Turath al-'Arabi, Lubnan, 1978.

18. Ibn Qudamah, 'Abdullah ibn Ahmad, al-Mughni, 1983, Vol. 7, Dar al-Fikr, Beirut.

19. Al-Suyuti, Jalal al-Din bin 'Abdul Rahman bin Abi Bakr. Ashbah wa Naza' ir fi Qawa'id wa Furu' Fiqh al-Shafi'iyyah. Beirut: Dar al-Kutub al-'Ilmiyyah; 2010 .

20. Muhammad Rif 'at. Qamus al-Tifl al Tibbi. Beirut: Dar al-Hilal, 1986.

21. Jelliffe, Derrick B, Jelliffe, Patrice, EF. Human Milk in the New Modern World: Psychosocial, Nutritional and Economic Significance. New York: 
Indian Journal of Public Health Research E Development, September 2019, Vol. 10, No. 09

Medical Oxford Publication. Kerr, Malcolm H. 2010. Abduh Muhammad. 15thEd. Chicago, IL: Encyclopedia Britannica Inc.

22. Maria H. The Importance of Breastfeeding to the Muslim Child. Accessed from mariahussain. wordpress.com, $3^{\text {rd }}$ January 2013.
23. Dogramasi, I. Breast-feeding in Islam. Accessed from www. islamset com/ hip/ dogramasi.Html, $2^{\text {nd }}$ January 2013.

24. Rida, Muhammad Rashid. Tafsir al-Manar. Beirut: Dar al-Kutub al-'Ilmiyyah, 2005, Vol. 2.

25. Al-Zuhayli. Tafsir al-Munir fi Akidah wa Syariah wa Manhaj. Vol. 5. Beirut: Dar al-Fikr, 1991. 